tells of Solomon's struggles with the king of the smiths, whose name appears to be Taamrinf. 86 (of cent. vii-viii) is a leaf containing an address of Christ to the Apostles. It may prove to be connected with the narrative described but not get published by C. Schmidt (Berlin, Sitsungsberichte, 1895), of which a fragment has recently been found by Bick in Latin in a Vienna palimpsest (Vienna, Sitsungsberichte, 1908).

88 has a small bit of a legend in which Jesus and John occur. One sentence runs as follows: 'But Jesus sat down (?) by the caldron... took three girths of wool and drew them through (?) the caldron; and the teacher looked.' This recalls (dimly enough) the miracle of Jesus and the dyer in the Gospel of Thomas.

Of the letters, one group $(268-276)$ is of cent. iv- $; 3^{11}, 3^{1} 3,396$ are of similar date.

The Bohairic MSS are mostly of later date. The most important of the New Testament texts have been described and used by Mr Horner, and the few apocryphal fragments by Forbes Robinson.

These notes are designed to draw attention to the points likely to be of special interest to readers of this Journal. It is obvious that the volume contains linguistic and lexical matter of the highest value to Coptic scholars, but of this I am not competent to form an estimate.

M. R. JAMES.

\title{
DOGMATIC THEOLOGY.
}

\section{A History of the Doctrime of the Eucharist. By DARWRLL STONE. 2 vols. (Longmans, London, 19o9.)}

THE author tells us that the present work arose out of his custom of forming lists of passages intended to illustrate the teaching of representative men and periods with a view to lectures on Christian doctrine. Many of the materials thus accumulated have already appeared in the writer's articles on the Eucharist in the Church Qwarterly Reviezo, and in a briefer form in the volume on The Holy Communion in the Oxford Library of Practical Theology. In the present work these materials have been supplemented and arranged. The result is a most complete thesaurus of passages bearing upon the history of the doctrine of the Eucharist from the period of the New Testament to the present day. The passages are given in English, and the task of translating them must have sorely tested the powers of the writer. If at times his renderings are open to question, the care and labour bestowed upon the task are deserving of all praise. Mr Stone expresses a justifiable dislike of scanty quotations. His own quotations are given at great length, and this fact, while it adds to the completeness of his book, makes it difficult to read, and does 
not allow sufficient scope for adequate discussion of the passages given. The grouping of the passages, in the earlier part of the work, according to the characteristic conceptions exhibited in them, supplies indeed some valuable guidance, and the summaries at the end of each important section belp to gather up their teaching. In the mediaeral and later period, however, there is less attempt to sort and arrange the quotations, and the result is somewhat bewildering to the ordinary reader. The desire of the writer to let his authorities speak for themselves stands rather in the way of his task as a historian. As a collection of materials for a history of the doctrine of the Eucharist the present work is invaluable. But it can scarcely be called a history in the fullest sense of the. word. The writer frequently does not come to sufficiently close quarters with the evidence which he handles; the sifting and critical analysis of the materials needs to be carried much further; lastly, a fuller comparison and criticism of the conceptions of different writers and periods seems needed before a judgement can be formed upon the worth and importance of the developements exhibited in the course of the history of the doctrine.

In his treatment of the accounts of the Institution in the synoptic gospels Mr Stone leaves on one side many of the important critical questions which have been raised with regard to them and their relation to the account given by St Paul in I Corinthians. He maintains the literal interpretation of the pords 'This is My Body', 'This is My Blood', and the

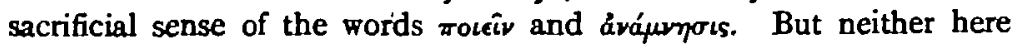
nor in his discussion of the prayers in the Didache and the language of Ignatius does he add much to previous discussions. Of more importance and value is his presentation of the divergent types of eucharistic doctrine current in the ante-Nicene Church. He illustrates at great length the use of the terms 'figure' and 'symbol' applied to the elements by many writers, and shews with what qualifications this language must be accepted as expressing their real view. In parts of the teaching of Clement of Alexandria and Origen he admits that there are 'affinities with the later opinions of some mystics and even of the Quakers' (i 54). The two types of eucharistic teaching exhibited in Augustine and Ambrose, and their influence on later Western teaching, are clearly shewn, and the treatment of Ratramn and Berengar is marked by judgement and reserve. Side by side with this developement of doctrine on the subject of the eucharistic gift, the sacrificial conceptions associated with the Eucharist are indicated, though perhaps hardly with the same analytical treatment.

Mr Stone writes sympathetically of the teaching of the schoolmen, to whose contributions to the doctrine of the Eucharist justice has not always been done by modern writers. He indicates the reserve 
exhibited in the language of the decree of the Lateran Council of 1215 , in that while the word transubstantiare is used 'there is no explicit definition as to the change of substance or as to the retention of the accidents' (i 313). There is something more to be said for a less rigorous interpretation of this decree than has commonly been allowed, though it must be admitted that the stricter interpretation of transwbstantiare became current from the thirteenth century onwards, and any other view was sternly repressed.

A history of the cultus which gathered around the Sacrament of the Eucharist in the Middle Ages has still to be written (a beginning has been made in Dr F. Pijper's Middelecurwsch Christendom: de verecring der $H$. hostie; de gads-ordeelen. Leyden, 1907). Its records are contained not so much in the works of schoolmen as in the hymns, popular manuals of instruction and devotion, local histories, popular stories of miracles, and contemporary general literature. It is this influence of popular religion, alike in the patristic and mediaeval period which needs to be dealt with before the history of the doctrine of the Eucharist can be adequately written. In this respect Mr Stone's treatment leaves something to be desired.

In his summary of mediaeval doctrine Mr Stone expresses his strong dissent from the view that 'the Eucharistic doctrine of the mediaeval Western Church was wholly or mainly mechanical and carnal' (i 397). He has a right to protest against much of the language that is commonly used upon the subject. But his own view of the matter is too favourable, and here again he scarcely allows sufficient weight to the influence of popular conceptions and practices on a period when religion was one of the most living interests of Western Europe. In some cases, as in his treatment of the statement drawn up by Cardinal Humbert in 1059, and of the language used by Lanfranc, he seems to minimize or tone down the crudity of the expressions used. Elsewhere he fails to take into account features of mediaeval practice which tend to diminish our respect for mediaeval religion. Such are the growth of the abuses arising from the chantry system, the popular conception of the application of the benefits of Masses apart from the moral condition of the morshipper, and the exaggerated language used with regard to the benefits of hearing Mass apart from Communion (see e.g. the Lay Folk's Mass Book $596 \mathrm{f}$ 'We pray this Messe us stand in stede of shrift and als of housel brede', cf. Lydgate Merita Missae 123 f). The work of the schoolmen in formulating a doctrine of the Eucharist was hampered by the fact that they inherited from the later patristic period and the early middle ages a system of belief and practice in which the cruder elements of popular religion had largely obtruded themselves. 
Mr Stone's second volume begins with the period of the Reformation, and carries down the history to the present time, including some notice of the treatment of the doctrine of the Eucharist by Modernist writers. In arrangement and method the second volume is inferior to the former, but it is a mine of information upon the later period.

Mr Stone's book will be indispensable to future students of the subject, and it is to be hoped that it may stimulate some competent scholar to utilize, and supplement from less direct sources, the materials which it contains, with a view, to the production of a critical and constructive history of the doctrine with which it deals.

\section{J. H. Srawley.}

Proprssor F. J. Hall has issued two more volumes of his ' Dogmatic Theology' (Longmans, Green \& Co., 1908, 1909). The title of volume II is Authority Ecclesiastical and Biblical. The principle from which Dr Hall works is that ecclesiastical as well as biblical authority is derivative from Christ, divinely guaranteed, and therefore infallible within its appointed range. The Church defines her dogmas through the episcopate, which in practice has meant through councils; but the decrees of councils are valid only in so far as the whole Church comes to accept them. Dr Hall seems to be unaware of the serious difficulties of this position. He tells us, for instance, that as there is a presumption that general councils will be guided by the Holy Spirit their decisions must not be rejected on mere private judgement, or till it becomes clear that the Church herself does not accept them. But how is the Church to accept or reject them save through the exercise of the private judgement of the individuals who compose the Church? Dr Hall seems to try to abstract the Church in an impossible way from its individual members, and so to demand the subjection of the individual's judgement to that of the Church, though elsewhere he implicitly asserts the necessity for dogmas agreed upon by bishops or councils to be ratified by the agreement of the Church, which must in this instance represent the opinions of the aggregate or the majority of the individuals composing the Church. The view which Dr Hall accepts, that a council is not to be held as ecumenical till its decisions are generally received, evacuates the principle of a living infallible voice of any use for practical religion. And one would like to ask whether be would say that the statement of the union of the two natures in Christ's Person, drawn up at Chalcedon and accepted afterwards, is incapable of revision now, when it is well known that many of our ablest theologians feel more and more the difficulty of that definition. Can the ecumenical Council of Chalcedon cease to be ecumenical now? If not, then indeed are we most stringently tied down to the heritage of the methods 